\title{
Technical Terms of Navya-Nyāya Language and its Methodology
}

\author{
Nibedita Banerjee, Anil Pratap Giri
}

\begin{abstract}
The Navya-Nyāya language ${ }^{1}$ (Neo-logic) exhibit one of the purest languages of human intellect. It has been assists India's intellectual academic culture and traditions. From the $10^{\text {th }}$ Century AD Navya-Naiyāyikas emphasized one-step further in intelligentsia and came out with a precise technical language which is a special form of Sanskrit-delimits ultimate mining of each and every word and capture reality as it is, destroy Jalpa and Vitandā kind of dialogues in intellectual countering amid different school of thoughts. Since Navya-Nyāya language is a peculiar language based on logic-thought and reality invented by Great Indian logicians that is why it has been treated an artificial language as well. Due to unique features of Navya-Nyāya language many traditional philosophical problems have been scientifically clarified and resolved. Navya-Nyāya methodology proved to be so multifaceted not just for philosophers, but also in poetics, linguistics, legal theories, and other domains of medieval Indian thought process. Apart from philosophers, Navya-Nyäya style of writing has also been adapted by grammarians, aestheticians and the scholars of rhetoric and poetry. The reason for this could be the ease of putting one's views methodologically and unambiguously when using Navya-Nyäya language for universal thinking. Navya-Nyāya made the evolution that there was Navya-Vyäkarana, Navya-Mīmāinsā and NavyaVedānta's new school of thoughts arose. These terms came into configuration only because of Navya-Nyāya and these other schools followed the footsteps of Navya-Nyāya very systematically. The focus of modern Navya-Nyāya was to define terms in a precise and particular manner and then to formulate or emerge a language which may be called 'the precise medium of communication'. It was necessary to evolve a new or should we say an artificial language to do away with the possible ambiguity, which is a basic quality of any natural language. Since natural language cannot be totally ambiguity-free, Navya-Nyāya can serve the academic needs. To understand our Indian Intellectual Traditions in medieval period or the actual meaning of our Śästras written after $10^{\text {th }}$ century AD, this Navya-Nyāya language and Methodology is highly efficient device. Without proper knowledge of Navya-Nyāya, intellectual development of aforementioned period cannot be properly known. Hence, this, paper would try to revive the basic features of Navya-Nyāya by analysing its technical terms so that it could serve contemporary academic needs and so on.
\end{abstract}

Key-Words: Methodology, Navya-Nyāya Language, Delimiter, Delimited.

\section{INTRODUCTION:}

- To understand the technical nature of the Navya-Nyāya Language and its methodology.

- To show that how meaning of the sentence can be delimited in this peculiar language through diagram.

- To justify: How word, meaning and its relationship are codified.

Revised Manuscript Received on June 13, 2020.

* Correspondence Author

Nibedita Banerjee*, Assistant Professor, Amritadarshanam International Centre for Spiritual Studies, Amrita Vishwa Vidyapeetham, Bangalore

Anil Giri, Associate Professor, Department of Sanskrit, Mahatma Gandhi Central University, Motihari

(c) The Authors. Published by Blue Eyes Intelligence Engineering and Sciences Publication (BEIESP). This is an open access article under the CC BY-NC-ND license (http://creativecommons.org/licenses/by-nc-nd/4.0/)
- To get scientific structure of this language, this can be used as a tool to develop information technology.

- To justify that Navya-Nyāya Language can be used as a medium of Communication to get an ambiguous free concept.

\section{OBJECTIVES:}

Analytical methodology is applied to analysis this paper. Through this analytical methodology, this paper analyses alphabetical form of logic and its relationship with language and reality.

\section{METHODOLOGY:}

Indian Intellectual Traditions mainly based on VedasKnowledge of truth. Vedas are the primary texts of Aparā knowledge, capturing most possible ultimate reality in the enhanced language for entering into Parā knowledge. As per Indian Intellectual Traditions two types of knowledge should be known. ${ }^{2}$ Parā has metaphysical entity. It is beyond the language. It can be realized and transmitted in silent mode from one to others. Initial Mantras of Śrīdakșiṇāmūrtistotraṃ represent the nature of Parā vidyā or Parā knowledge and its methodology, which justifies that it cannot be communicated through language. ${ }^{3}$ Aparā knowledge has been captured in the most powerful language is called Sanskrit. Sanskrit literature, Kāvya Śastra means science of knowledge which is broadly categorized into two disciplines-Apaurușeya and Paurușeya. ${ }^{4}$ Apaurușeya Sāstraa without known beginning text comprises four Vedas Rgveda, Yajurveda, Sāmveda and Atharveda, ${ }^{5}$ Brāhmaṇas-( Explanatory texts of Vedas in terms of rituals), Āryanaka (Texts of Inherent meaning and implications of Vedas), Upanișads- (Preaching texts consisting ultimate meaning of Vedas) Āyurveda -(Scientific knowledge of healthy life), Dhanurveda -(Science of weaponry), Gāndharvaveda (Scientific knowledge of art and aesthetics), Śilpaveda-( Scientific knowledge of architecture, Nātyaveda -(Scientific knowledge of plays) based on peripheral Six essential disciplines are called Six Vedāngas. These Six Vedāngas formed the first systematic corpus of Indian knowledge system i.e. Śikșā, Kalpa, Vyākaraṇa, Jyotișa, Chanda and Nirukta ${ }^{6}$. Apaurușeya- (is a technical Sanskrit term meant for specialized intellectuals-free from time, place and author's dogmas. Pauruśeya Śāstras are time, place and author bound texts meant for competent intellectuals who are technically dedicated in acquiring and possessing the knowledge.

Published By:

Blue Eyes Intelligence Engineering

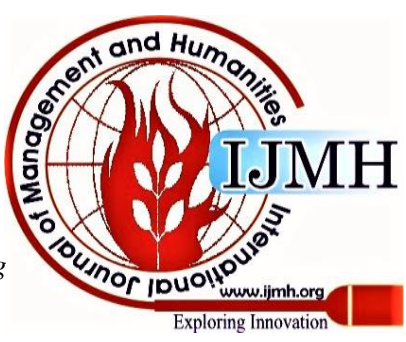


Pauruśeya Śāstras - are divided into four schools of thought initially extended upto five i.e. Purāṇas, Mimāmsa, Ānvavīkșī, Dharmaśâtras, and Sāhityavidyā. ${ }^{7}$ There are 18 major purāṇas. ${ }^{8}$ Two Mīmāmsā schools of thought named Purva-mīmāinsā, Uttara-mīmāmsā -logically interpretation of Vedic sentences for universal rules and regulations of ritual activities and justify ultimate knowledge successively. $\bar{A} n v \bar{i} k s ̦ i ̄ k \bar{l}-$ Critical investigation of truth consists atheist, and theist philosophical systems. Ānvikșikī-Indian logic system, actually deals with knowledge and discussion on the truth of life. This Ānvikșikī developed Indian philosophical systems. Major Indian Philosophical Systems are- Nyāya, Vaiśeșika, Sāmkhya,Yoga, Buddhist, Jaina and Cārvaka. Aforementioned philosophical systems are classified into atheist and theist. Atheist philosophers are those who do not believe in the authoritativeness of the Vedas broadly classified into Cārvāka, Bauddha, Jaina. Theist philosophers are those who believe in the authoritativeness of the Vedas broadly classified into Sāmkkhya, Yoga, Nyāya, Viașeśika, Pūrva-Mīmāmsāa and Uttara Mīmāmsā extended to many philosophical schools.

Vedānta or Uttara Mīmāmsā is interpreting the Upanișadic sentences in terms of Knowledge itself as a Brmahaṇa. Pūrva-Mīmāmiāa (Hermeneutics) is a science of interpretation-how to interpret Vedic sentences in terms of rituals. Nyāya providing the tool of argumentation, proving the methodology to reached the ultimate truth. Vaiśeșika tries to understand the whole world through language. Sāmkhya explains the theory of evolution of Universe. Yoga is a deep applied psychology provides tools of enquiring to discover inner world. This is a brief introduction to Indian philosophical Systems which is delimited by Ānvīkṣkī. Without the knowledge of Nyāya Vidyā no discipline can be flourished that is why Kaūtilya praises an importance of Nyāya vidyā in his text named Arthaśāstra-

Pradīpaḥ sarvavīdyānām upāyaḥ sarvakarmaṇām

Āśryaḥ sarvadharmāṇām śāsad ānvīkṣkīi matā Arthaśāstram-1.1

\section{HISTORY OF NAVYA-NYĀYA LANGUAGE}

Nyāya philosophy accepted as the realist and reconstructed knowledge as the name of Navya-Nyāya. It claims that this pluralistic world is real and this reality can be proved on the basis of two criteria i.e. Knowledge and Language (Nāmarūpātmakaṃ Jagataṃ). $10^{\text {th }}$ century A.D seems to be the turning point in the development of NyāyaVaiśeșika philosophical system. There is a shift emphasis from prameya (Knowable) to pramāṇa (Epistemology), from ordinary Sanskrit language to Navya-Nyāya language, from product to process, from traditional thinking to new way of thinking- known as Navya-Nyāya. This period marks the beginning of Nyāya-Vaiśeșika philosophers engaging in preparation of precise language of discourse. In Nyāya sāastra Nyāya is particular, it is the significance of particularity. But in Navya-Nyāya language, Navya-Nyāya is general. In $13^{\text {th }}$ century Navya-Nyāya, the school of Indian philosophy stands apart from other schools of thought in the sense. The neo logician developed this technical language and it became the language of all Sāstric discourses in India. It is generally agreed that the father of
Navya-Nyāya was Gañgesopādhyay, a Brahmin logician of Mithilā at $14^{\text {th }}$ century A.D. ${ }^{9}$ He wrote the book Tattvacintāmani ${ }^{1}$, which lead the foundation of a school. The school of philosophy is rigorously rational by emotion or mystical experience as the analytical school of modern west ${ }^{2}$. It creates a dissent trend of our thought and diction in the field of logic, epistemology and theory of language. In 1976, the Nyāyasiddhāntadipa of Śaśadhara has come to light. This is argued to be prior to Gangesa by Bimal Krishna Matilal who critically edited the text. Actually, for the knowledge of Navya-Nyāya, this abstract and profound work has been the basic text and the whole system has developed for the next seven hundred years more by the help of commentaries, sub-commentaries, critical notes, expository accounts and glosses on it. Once this language was developed by the $13^{\text {th }}$ century A.D, all thinkers and philosophers adopted this very Navya-Nyāya language to analyse a thought and wrote books in their respective fields of discourse.

\section{NATURE OF NAVYA-NYĀYA LANGUAGE}

Navya-Nyāya Language is an artificial language. It has been created by Indian logicians from the natural Sanskrit language. This is why it is not without known beginning language as natural languages are having an attribute. Where all-natural languages possess ambiguities, there NavyaNyāya Language is fully ambiguity free language. Where words of all-natural languages deviated time to time, space to space, there Navya-Nyāya Language is deviation free language. Where relationship between word and its real meaning is not scientifically structured in the natural language there Navya-Nyāya Language deals with scientific structure of the relationship between word-meaning and reality. Where natural language has quality of elaboration that opens the scope of misunderstanding, debate there Navya-Nyāya Language has quality of abstraction that opens the scope of scientific understanding of the reality and ends the scope of unnecessary debates, intellectual quarrels etc. Where natural language is non-created language there Navya-Nyāya Language is created by Indian logicians and adopted by all major Indian school of thoughts later $14^{\text {th }}$ century onwards in their writings. Due to these abovementioned peculiars qualifies of Navya-Nyāya Language, it became very powerful medium of intellectual discourse after $10^{\text {th }}$ century AD in the field of Sanskrit in general and in the commentary writing traditions in particular. Hence linguistics study of Navya-Nyāya Language is must in postmodern era.

\section{STRUCTURE OF THE NAVYA-NYĀYA LANGUAGE}

Nyāya tradition is divided into two phases:

1. Nyāya tradition before $10^{\text {th }}$ century AD.

2. Nyāya tradition after $10^{\text {th }}$ century AD.

First phase adopted general Sanskrit language in its writing and second phrase adopted Navya-Nyāya Language in its writing.

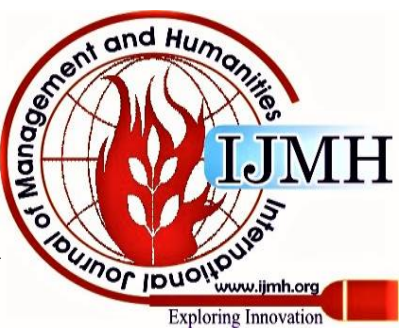


Writing in general Sanskrit language could not solve the problem of ambiguity, opaqueness of understanding, universal model of thinking and precise model of discourses. For dissolving all those problems great logicians have created Navya-Nyāya Language in the name of neo-logic which was formally founded by Gangeśopādhyaya in the $14^{\text {th }}$ century $\mathrm{AD}^{1}$, when he wrote a wonderful text of Nyāya philosophy in the Navya-Nyāya language named "Tattvacintāmanii".

In the Navya-Nyāya Language, contents are precise, meaning of the sentence is ambiguity-free and free from opaqueness, and words of the sentences are technical and delimit meaning of the sentences. Dialogue between speaker and hearer occurs as it is. This language does not represent the particular culture or region. Each word is highly technical reveals specific meaning that is why it's called as a defined language. Due to abovementioned properties of this language it has become so popular between $14^{\text {th }}$ Century and $19^{\text {th }}$ Century A.D. in greater India which was not only adopted by logicians but Grammarians, Poeticians Vedāntins and other Indian intellectuals as well.

\section{PROPERTY OF NAVYA-NYĀYA LANGUAGE}

Navya-Nyāya Language is an artificial Language.It is a product of Indian logicians who involved in logical discourse with Buddhist logicians for inquiring ultimate reality. It has invented a new methodology of language in which word maps its meaning. It has focused on structure of the world and came out with following findings:

1. The World is real.

2. It exists in human mind.

3. It is created neither by human mind nor imaginary.

4. It is dependent on human mind.

5. It is not mental projection.

6. Human mind can know the world and can name as well.

7. The World is not mental construction.

8. The World is given.

9. The World may become an object of knowledge.

10. The World can be communicated through language.

11. The world can be logically encoded in the form of cognition.

12. The World can be logically decoded in the form of language.

13. The World and Word are equivalent to each other.

14. Navya-Nyāya language reconstructs transcultural and

15. Navya-Nyāya language refers to the World. The world is seven referents only which are real and well structured. Navya-Nyāya language captures these seven referents in the form of Dharma-Dharmi-bhāva relationship.

Modern Indian Logicians emphasized on world which is well structured and very simple. If the world is structured then it can be captured in structured language. Structured language is a technical language based on logical Dharma and Sambandha. Each word of this language is technical therefore the form of the sentence is also technical and concise which needs to proper training to grasp by knowing its methodology. Herewith, there are few examples given to proof aforementioned attributes: transregional intellectual tradition.

\section{A. Technical term - Ghațatvavān}

Syntactical analysis of Ghațatvavān ${ }^{10}$ is based on substratum-superstratum relationship in the Navya-Nyāya Language. Without knowing the methodology of substratum-superstratum relationship in terms of Ghațatvavān the syntactical meaning of this sentence will not be clear to us. Analysing this sentence in general Sanskrit named as 'Ghața'. In the general Sanskrit sentence, it can syntactically analyse as "Ghațạ iti" ${ }^{11}$ understanding of this sentence makes ambiguity viz. what is Ghața? Is it colour or shape or size of Ghața or something else? But in Navya-Nyāya Language it is called Ghațatvavān. Ghațatvavān is a precise sentence, which makes absolute clarity of understanding of 'Ghața'. 'Ghațatvavān' is a Code of 'Ghața specific -referent' can be de-codified as "Ghațatvanișthādheyatānirūpitādhikaraṇatāvān"12. The diagram below can be used to understand this sentence through Navya-Nyāya language.

“Ghațatvaniṣthādheyatānirūpitādhikaraṇatāvān Ghațạ̣"

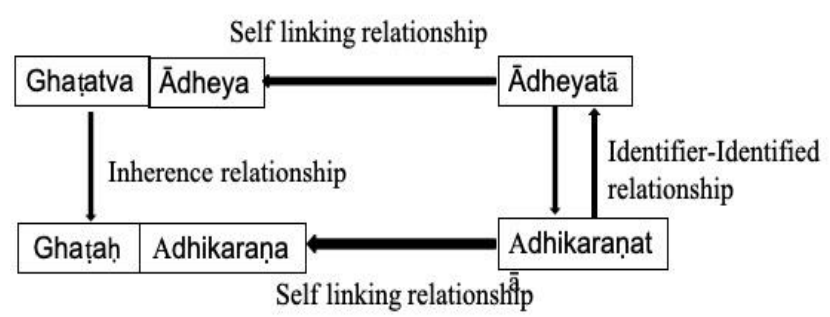

Here, Ghața is a Substratum and Ghațatva is superstratum. The relationship between Ghața and Ghațatva is substratum superstratum relationship. Ghața is substratum because Ghațatva resides in Ghața by inherence relationship. Ghațatva is superstratum because it exists in Ghața. Ghațatva possesses superstratumness which is created property of Ghatatva resides in by self-linking relationship. Ghata is substratum in the context of Ghațatva, possesses substratumness which is created property resides in by selflinking relationship. Ghața is identified by superstratumness. Ghațatva is identified by substratumness. Superstratumness and substratumness are identified by each other. In the same manner, Ghața is substratum of Ghațatva, then Ghața has substratumness which has been identified by superstratumness. Therefore, wherever there is Ādhārah, there has to be some ādheyah which describes the ādhārah of the ādheyah. Overall Ghațatvavāna maps entire meaning in unambiguous nature i.e. Ghațatva possesses superstratumness which identify Ghața in which substratumness exists or it can be understood in vice-versa mode i.e. Ghațanișțhādhikaraṇatānirūpitādhyeyatāvād ghațtvaṃ. Here, ghața possesses substratumness which identify Ghatatva in which superstratumness exists.

Methodology of inherence relationship in terms of Ghațatvavān: The inherence relation occurs between Ghața with Ghațatva. In general Sanskrit we can say Samavāyena Ghațatvavān Ghațạ̣ But in Navya-Nyāya language: 'Samavāyena ghațatvaniṣthādheyatā nirūpitādhikaraṇtāvān Ghațah’.

Published By:

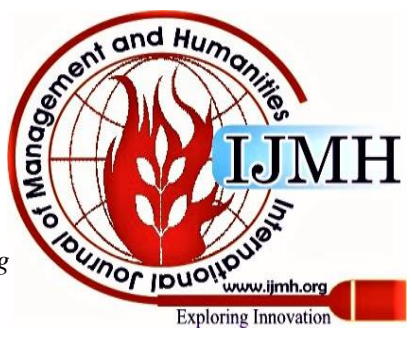


The relationship plays major role of understanding of object. Structure of inherence relationship in terms of Ghațatvavān can be analysed through diagram. Methodology is inherent in the structure itself. Revealing structure -reveals methodology automatically.

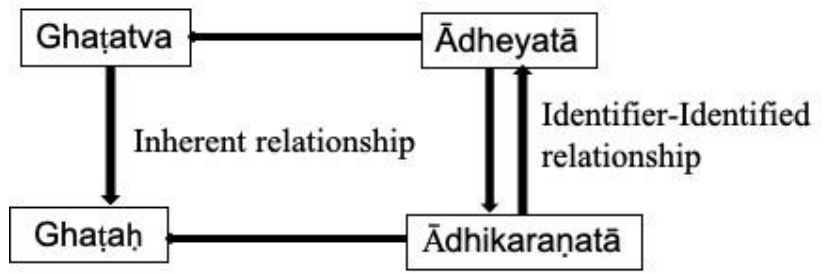

If we take the example of Pot and Potness then pot and potness are two different entities but both the entities connected each other through inherence relationship. Different entities connect by relationship. Here, pot is substance and potness is universal. Both substance and universal are separate referents in Navya-Nyāya. When these two referents connected to each other. They will be connected forever. Relation between these two is called ayutasiddha-sambandha or eternal relationship. ${ }^{13}$ Pot is property-holder and potness is the property of the pot called Jāti or universal in Navya-Nyāya Language. Universal resides in its locus always by the relation of inherence, and never by any other relation. Pot is location (ādhāra), possessing potness as dharma, potness is locative (ādheya) of Pot. Relationship is dharma-dharmibhāva-sambandha or ādhāra-ādheya-bhāva-sambandha (location-locative relation). If pot and potness are related by inherence relationship, the question arises, how its inherence related to pot and potness. This question is valid because unless inherence is related to both, they cannot be said to be related. Here, it must be cleared that inherence is also a separate entity in Navya-Nyāya. In the context of aforesaid we get three separate entities connecting each other and making one cognition viz. Pot, potness and inherence relationship. Inherence connects both potness and pot but inherence itself is connected to potness and pot by selflinking relationship. one Understanding of this sentence is like this: Ghața iti jñānam ghața-vișeșyakam ghațatva prakārakam samavāya-saṁsargaka jñānaṃ. Here, the knowledge of pot is viz. pot is qualificand and potness is qualifier, related to pot by inherence relationship.

Now we could see how Navya-Nyāya Language has controlled the meaning of Ghațatvavān by inherence relationship has demolished ambiguity of understanding an opaqueness. Where in general Sanskrit samavāya is a qualifier of ghațatva or ghațatva is a qualifier of samavāya is not cleared - makes a lot of confusions and how ghaț associated with ghațatva and samavāya are not cleared as well - make ambiguity and opaqueness. Whereas Ghața can give primary meaning, intended meaning and suggestive meaning in general Sanskrit there as Ghațatvavān gives only primary meaning that leads to an un-ambiguity. The above diagram explains methodology of inherence relationship in the context of Ghatatvavān i.e. pot possesses potness. Potness is inherent property of the pot. Potness exists in pot by inherence relationship. The locus of potness is pot. Potness is located and pot is locus. Relation between pot and potness is locus-located-relationship. Since potness is located therefore, locatedness as a created property resides in potness by self-linking relationship. In the same manner pot is locus therefore locusness as a created property resides in pot by self-linking relationship. Locusness and locatedness have a mutual expectancy, both of them are related by the mutual relation of identifier and identified. Locusness is identified by locatedness and locatedness is identified by locusness. Thus, potness possesses locatedness identified by the pot; or: the potness possesses locatedness identified by the locusness residing in the pot.

B. Methodology of counter-relatum and base-relatum relationship in terms of Ghațatvavān

If we take any negation sentence in general Sanskrit it "Saṁyogen ghattvaṃ nāsti"- this is general Sanskrit language. It can be written in Navya-Nyāya Language as "Saṁyogensaṃbandhāvacchinna Ghaṭatvaniṣthāprotiyogitā nirupakaḥ abhāvavān Ghațạ"

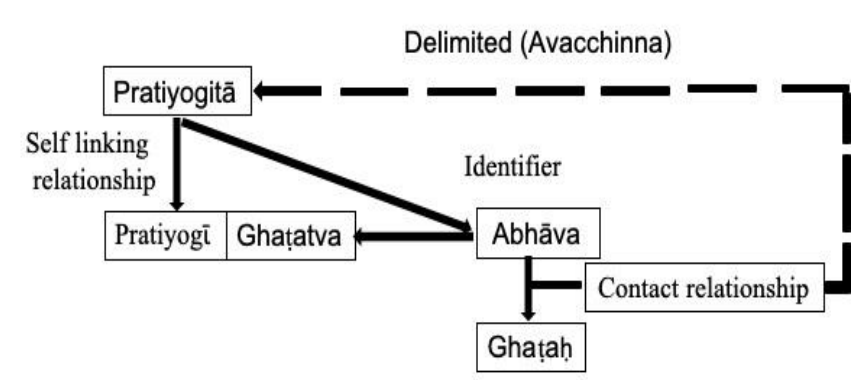

Ghațatva is absent in Ghața by contact relationship. Here potness is counter positive of pot and pot is the base-relatum of contact relationship. As the relation of contact specifies the counter positiveness (pratiyogītā) of absence of potness in pot. The counter positive possesses the counter positiveness by self-linking relationship. Base-relatum also possesses base relatumness by self-linking relationship. The relation is the delimiter of the counter positiveness by the relation which is intended to be absent in a pot. Here, the counter positiveness of potness in pot is specified by the relation of contact. In other words, potness is absent in pot by contact relationship but it presents in the pot by the relationship of inherence. This counter-positiveness of the absence of potness, as delimited by the relation of contact, is the representation of Navya-Nyāya language. Thus, the relation between the relation of contact and the counter positiveness in potness is delimiter delimited relationship. Here, absence has one counter-possibility and one locus. Ghața is the locus of absence. Ghața possesses base-relatum (anuyogī) and Ghațatva possesses counter-positive (pratiyogī) of abhāba (absence). Contact relation delimits counter positiveness (pratiyogītā) which resides in Ghațatva. Here Each Sentence reveals an absolute concept. Even this Concept and Facts are equivalent. Navya-Nyāya Language is restricted Language because it delimits the meaning of the sentence. It clarifies the relationships between property and property-holders, restricting the essence of the sentence.

Hence, Navya - Nyāya Language is the product of human computing which can be tool for computational linguistics for making programming languages. It can solve the problem of an ambiguity and misunderstanding of the communication.

Published By:

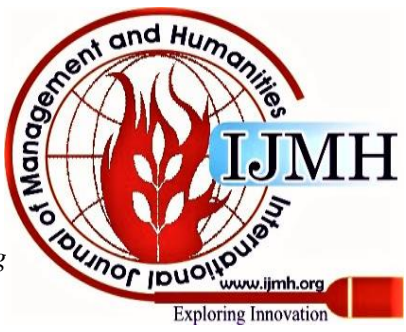


For mapping the meaning of the sentence, it can be tool for the modern linguists. It creates the most analytical valueoriented rationalist mind. It is free from cultural identity; it could solve the problem of language-based power politics. It is very professional language, which can supply the market needs. It could solve the struggle problem between westernised and Indian rational cultural. It makes one of the most intellectual societies among plural cultural society.

\section{RESULT ANALYSIS}

The methodological understanding of Navya-Nyāya terms would provide a golden opportunity for entering into the garden of Indian Intellectual Traditions. The great Indian knowledge systems from $1000 \mathrm{AD}$ to $1800 \mathrm{AD}$. are mostly bypassed through Navya-Nyāya language. Indian intellectuals of this phase have applied Navya-Nyāya language as a tool for precise communications so that intellectual discourse could free from all the doubts, which resulted scientific temperament,clarities in thoughts, to the point dialogue technique for both speakers and listeners. Almost 1000 years of Indian Intellectual Traditions were surcharged by this artificial Navya-Nyāya language. Therefore, Knowledge of technical terms of Navya-Nyāya is a key to open serious studies of Indian Intellectual, philosophical and spiritual traditions which exist in the form of Sutra,Commentary, Independent text,Multidisciplinary text,Interdisciplinary text and so on. In large numbers of Sanskrit text written in Navya-Nyāya language in the form of manuscripts laying down in various Manuscripts libraries, Mathas, Temples, and Other places are still unutilised due to the lack of methodological understanding of Navya Nyāya. The scientists will acquire a tool to analyse those coded human thoughts in Navya-Nyāya language by analysing methodology of Navya-Nyāya language. Language technologists will get the knowledge to do information technological developments and experiments in the field of information technology in general and in the field of artificial intelligence and machine translation in particular. Social scientists will come to know how clarity can be achieved through judicious manipulation of natural languages. Artists will come to know how an abstract idea can be concretised. Human scientist will get the methodology of expressing metaphysical ideas. Therefore, this paper would help in various disciplines like Sanskrit, Philosophy, Languages, Linguistics, Computational Linguistics, Human Sciences, Social Sciences, Manuscriptology, Art and Aesthetics, Language technology, Machine translation.

\section{CONCLUSION}

Hence, the methodology of Navya-Nyāya Language makes understanding clear which can be the part of the linguistics. Structure of this language is too scientific. Each word has delimited meaning in the sentence which reflects in the form of systematic arrangement of the sentence. Navya-Nyāya sentence not only deals grammatical structure and relationship between words to word but it deals ultimate meaning of the respective sentence also. A uniqueness of this language is that it delimits boundary of the meaning of the sentence. There are no secondary or tertiary meanings are accepted of the Navya-Nyāya Sentence. Primary meaning of the sentence is particular sequence. There is a system of getting primary meaning from the Navya-Nyāya sentence which makes universal understanding. In this regard Navya-Nyāya Language has major significance in the field of linguistics and language technology in the contemporary society.

\section{REFERENCES:}

1. International Alphabet of Sanskrit Translation (IAST) scheme has been used to represent Devanagari words in Roman alphabets.

2. Tasmai sa hovāca. Dve vidye veditavye iti ha sama yadabramhavido vadanti parā caivāpara ca- Muṇụakopanișad,1.1.4

3. Citram̉ bața tarormūle bṛdhāḥ śiśyāḥ gururyuvāḥ

4. Gurostu maunam vyakhyānam śișyāstuchinnasamiśyāh Śrīdakșiṇāmūrtistotram,03

5. Kāvya-Mīmāmsāā,1.2, p.20

6. Ibid,1.2, p.20

7. Ibid,1.2, p.21

8. Paṁcamī sāhityavidyā iti yāyāvarīyah- Kāvya-Mīmāmsā,1.2, p.26

9. Aśțādaśaiva srutyarthsmaraṇātsmṛtayaḥ- Kāvya-Mīmāmsāā,1.2, p.25

10. Jha,Ujjwala, A primer of Navya-Nyāya Language and methodology, Navya-Nyāya Bhāsā-Pradipa of Mm. Mahwh Chandra Nyāyaratnar, English translation (with Graphic Exposition), The Asiatic society, 1 park street, Kalakata, introduction, Page no-9.

11. Varkhedi , Shrinivas, Knowledge representation: Navya Nyāya and Conceptual Graphs,1.2.1.1,p.3

12. Varkhedi , Shrinivas, Knowledge representation: Navya Nyāya and Conceptual Graphs,1.2.1.1,p.4

13. Varkhedi , Shrinivas, Knowledge representation: Navya Nyāya and Conceptual Graphs,1.2.1.1,p.4

14. Samavāyo nityasambandhạ ityucyate. Samavāyasyaiva Ayutasambandha iti nāmantaram., Navya-Nyāya-Bhāṣā-Pradīpa ,p.39

\section{AUTHOR PROFILE}

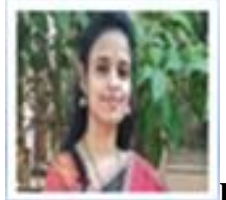

Dr. Nibedita Banerjee, currently serves as Assistant Professor at Amritadarshanam - International Centre for Spiritual Studies, Amrita Engineering College, Bengaluru campus. She completed her Masters from Banaras Hindu University. She has been awarded 'Doctorate of Philosophy' from the Department of Sanskrit, Pondicherry Central University. Her thesis topic was "A Study of Navya-Nyāya Language and Methodology of First Ānana of Rasagangādhara in the light of Madhusūdanī-Vivriti”. She teaches Indian Culture and Value based education as connected with Indian Intellectual traditions to undergraduate and masters level engineering students. Out of this, her area of Interest is Navya-Nyaya Language \& Methodology, Indian aesthetics, Manuscriptology \& Paleography.

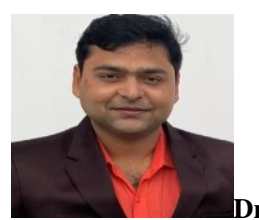

Anil Pratap Giri, is serving as an Associate Professor at Department of Sanskrit in Mahatma Gandhi Central University,Bihar. He has been starting his academic carrier as an Assistant Professor, Department of Sanskrit, Pondicherry University since 2010. He earned his M.A., M.Phil. and Doctorate from the School of Sanskrit and Indic Studies, Jawaharlal Nehru University, New Delhi.Dr. Giri is the author of two books of literary criticisms. He has published closed to 45 research articles. He is teaching social, economic, political, philosophical, and spiritual issues in the light of Sanskrit Creative Writings, Sanskrit Translation, Navya-Nyaya Language \& Methodology, Poetics, Indian Knowledge System, Indian Philosophical System, Linguistics, Grammar and Manuscriptology.

Published By:

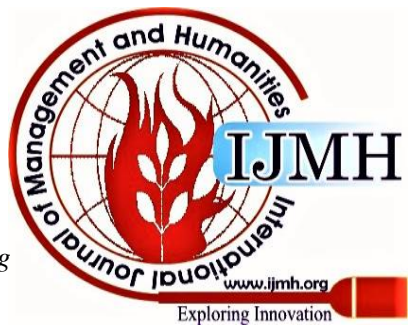

